\title{
Effects of Long-Term Fertilization on Different Nitrogen Forms in Paddy along Soil Depth Gradient
}

\author{
Xinyue Li'1, Bing Li ${ }^{*}$, Changquan Wang 1 , Yulan Chen ${ }^{2}$, Peng $\mathrm{Ma}^{2}$ \\ ${ }^{1}$ College of Resources, Sichuan Agriculture University, Chengdu, China \\ ${ }^{2}$ Liangshan Branch of Sichuan Tobacco Company, Liangshan, China \\ Email: *benglee@163.com
}

How to cite this paper: Li, X.Y., Li, B., Wang, C.Q., Chen, Y.L. and Ma, P. (2020) Effects of Long-Term Fertilization on Different Nitrogen Forms in Paddy along Soil Depth Gradient. American Journal of Plant Sciences, 11, 2031-2042. https://doi.org/10.4236/ajps.2020.1112143

Received: November 8, 2020

Accepted: December 11, 2020

Published: December 14, 2020

Copyright $\odot 2020$ by author(s) and Scientific Research Publishing Inc. This work is licensed under the Creative Commons Attribution International License (CC BY 4.0).

http://creativecommons.org/licenses/by/4.0/ (c) (i) Open Access

\begin{abstract}
The combined application of organic fertilizer and chemical fertilizer is an effective measure to increase nutrient content of soil plough layer, which must have a profound impact on the deep soil nutrients, especially the contents of nitrogen forms. The purpose of this study was to explore the characteristics of soil nitrogen forms in plough layer and along depth gradient in different fertilization treatments, so as to evaluate the soil quality in spatial dimension, further providing a theoretical basis for scientific fertilization and improvement of paddy soil fertility. Here, a 34-year field experiment was conducted with three treatments: without any fertilizer (CK), pure chemical fertilizer (NPK) and chemical fertilizer combined with organic fertilizer (NPKM). We analyzed the content of nitrogen forms in $0-100 \mathrm{~cm}$ soil depth and their ratios to total nitrogen (TN), and discussed the correlation between nitrogen forms contents and $\mathrm{pH}, \mathrm{CEC}$. Results showed that, compared with CK, both NPK and NPKM significantly increased the contents of nitrogen forms in topsoil (soil layer of $0-20 \mathrm{~cm}$ ), especially nitrate nitrogen $\left(\mathrm{NO}_{3}^{-}-\mathrm{N}\right)$ content increased by $70 \%$ (NPK) and $111 \%$ (NPKM), respectively. Although the contents of different nitrogen forms decreased gradually along soil depth gradient, NPKS slowed down the decline rate of TN and alkali-hydrolysable nitrogen (AN) in $0-60 \mathrm{~cm}$ soil layer, compared to CK. Compared to NPK, NPKM significantly increased the $\mathrm{NO}_{3}^{-}-\mathrm{N} / \mathrm{TN}$ ratio in $0-20 \mathrm{~cm}$ soil layer, but also decreased the content of $\mathrm{NO}_{3}^{-}-\mathrm{N}$ in $20-40 \mathrm{~cm}$, which was beneficial to reduce the risk of nitrogen leaching caused by nitrate leaching into deep layer. The increase of soil $\mathrm{pH}$ in NPKM treatment obviously alleviated the problem of soil acidification caused by long-term application of chemical fertilizer. Correlation analysis showed that there was a significant positive correlation between soil nitrogen forms and cation exchange capacity (CEC), but no significant correlation with soil $\mathrm{pH}$. In conclusion, NPKM ensured the
\end{abstract}


nutrients of soil plough layer $(0-20 \mathrm{~cm})$, also reduced the risk of nitrogen infiltration and nitrogen loss, thus ensuring the fertility of soil profile.

\section{Keywords}

Long-Term Fertilization, Soil Depth Gradient, Total Nitrogen, Nitrogen Form

\section{Introduction}

Rice is the main food crop in China, and its planting area has increased from 25.4 million $\cdot \mathrm{hm}^{2}$ to 31.4 million $\cdot \mathrm{hm}^{2}$ with per unit yield that has increased from $1.9 \mathrm{t}$ to $6.3 \mathrm{t}$ in the past 50 years [1]. Rice belongs to ammonium-loving plants. When nitrogen supply is sufficient, the roots and tillers of rice will increase rapidly, so nitrogen plays a key role in the yield and quality of rice [2]. Therefore, fertilization is one of the most important agronomic measures to increase grain production, resulting in an increase in the amount of chemical fertilizer year by year. However, excessive chemical fertilizer may cause nutrient loss and reduce fertilizer use efficiency, which is not conducive to higher crop yield and soil fertility [3]. Rational application of nitrogen fertilizer has been a key measure to obtain higher target yield in crop production in the world, and it is of great significance to alleviate the problems of soil quality degradation, rice yield and quality decline, environmental pollution and so on [4].

More than $90 \%$ of the nitrogen in the soil exists in organic form, and only $10 \%$ of the inorganic nitrogen can be directly absorbed and utilized by plants. Inorganic nitrogen is mainly mineral nitrogen like nitrate nitrogen $\left(\mathrm{NO}_{3}^{-}-\mathrm{N}\right)$ and ammonium nitrogen $\left(\mathrm{NH}_{4}^{+}-\mathrm{N}\right)$, which is not only easy to leach and volatilize from soil, but also can be fixed by soil clay minerals and organic matter. So the nitrogen in soil that can be directly absorbed and utilized by plants is often insufficient [5]. Field management measures such as tillage and fertilization significantly changed the distribution of soil inorganic nitrogen [6], and then affected the overall soil quality along the soil depth gradient. Li et al. [7] pointed out that the content of total nitrogen (TN) in red soil decreased gradually with soil depth and tended to be stable after $60 \mathrm{~cm}$. There was a positive correlation between nitrogen application rate and soil alkali-hydrolysable nitrogen (AN), but long-term application had no significant effect on soil TN [8]. In addition, long-term nitrogen fertilizer accumulated $\mathrm{NO}_{3}^{-}-\mathrm{N}$ rather than $\mathrm{NH}_{4}^{+}-\mathrm{N}$ content in $100-180 \mathrm{~cm}$ soil layer of dryland [9] [10]. Scientific fertilization can provide effective nitrogen source in time, ensure higher yield of rice and improve soil fertility. Organic fertilizer can increase the AN content of brown soil and avoid a large amount of nitrogen loss due to the rapid increase of soil nitrogen [11]. The input of organic fertilizer also greatly reduced the $\mathrm{NH}_{4}^{+}-\mathrm{N}$ and $\mathrm{NO}_{3}^{-}-\mathrm{N}$ in the runoff of the tea garden, which effectively improved the fertilizer use efficiency and reduced the environmental pollution [12]. The change of nitrogen in the 
surface layer of soil will inevitably have a profound impact on the nitrogen forms in the deep layer. However, due to the lack of attention to the distribution of nitrogen in soil profile, the change of soil quality cannot be better evaluated.

The long-term positioning experiment adopts the special research method of both "long-term" and "positioning", and cultivates the farmland ecosystem with remarkable advantages such as long-term time, climate repeatability, and geographical location and so on. It is a key platform for carrying out scientific research and discovering major scientific problems [13] [14] [15]. Field management measures such as fertilization and tillage have a great impact on the soil properties. Positioning experiment with long-term, stable and systematic can observe these significant changes and reduce individual errors [16] [17]. At present, many scholars have done more research in dryland soil and purple soil of long-term fertilization [18] [19], but there are few reports on the distribution of nitrogen forms along the depth gradient of paddy, especially combined with long-term positioning experiment. Therefore, this experiment mainly studied the effect of 34-year positioning fertilization on nitrogen forms in paddy soil profile, and explored the influence factors and vertical change law of soil nitrogen content in fertilization treatments. This result is expected to systematically understand the changes of paddy fertility, further providing scientific basis for scientific fertilization and improvement of soil quality.

\section{Materials and Methods}

\subsection{Site Description}

The experiment was established in 1984 at the "National cultivated Land quality Monitoring Point" in Deyang City, Sichuan Province, Southwest China $\left(30^{\circ} 58^{\prime} 19^{\prime \prime} \mathrm{N}, 104^{\circ} 44^{\prime} 23^{\prime \prime} \mathrm{E}\right)$. The experimental site, which is located in the hilly area of the Sichuan Basin, belongs to the subtropical humid monsoon climate zone, at an altitude of 332 meters, with a mean annual temperature of $16.7^{\circ} \mathrm{C}$, mean annual precipitation of $900-950 \mathrm{~mm}$ and annual average sunshine hours of 1000 - 1300 hours. The parent material of soil formation belongs to the alluvial alluvium weathered by thin sand and thick shale of Lower Cretaceous, and the soil type is paddy soil.

\subsection{Experimental Design}

In the field experiment with three plots: without any fertilizer (CK), pure chemical fertilizer (NPK) and chemical fertilizer combined with organic fertilizer (NPKM). There is no repetition, with the area of $866 \mathrm{~m}^{2}$ (Figure 1). The planting system is wheat-rice rotation. Wheat is sown in October and harvested in May; rice is planted in May and harvested in September every year. In 2017-2018, in NPK plot, the fertilizer application was $\mathrm{N} 132.23 \mathrm{~kg} \cdot \mathrm{hm}^{-2}, \mathrm{P}_{2} \mathrm{O}_{5}$ $34.54 \mathrm{~kg} \cdot \mathrm{hm}^{-2}$ and $\mathrm{K}_{2} \mathrm{O} 48.88 \mathrm{~kg} \cdot \mathrm{hm}^{-2}$ in wheat season, and $\mathrm{N} 183.51 \mathrm{~kg} \cdot \mathrm{hm}^{-2}$, $\mathrm{P}_{2} \mathrm{O}_{5} 34.54 \mathrm{~kg} \cdot \mathrm{hm}^{-2}$ and $\mathrm{K}_{2} \mathrm{O} 48.88 \mathrm{~kg} \cdot \mathrm{hm}^{-2}$ in rice season. In NPKM plot, on the basis of the same fertilizer as NPK, the application of organic fertilizer was about $5000 \mathrm{~kg} \cdot \mathrm{hm}^{-2}$ (Table 1). 


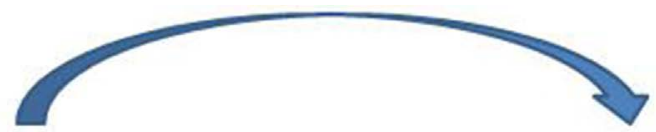

\begin{tabular}{|l|l|}
\hline \multicolumn{2}{c|}{ Ditch } \\
\hline NPK-1 & CK-1 \\
\hline NPK-2 & CK-2 \\
\hline NPK-3 & CK-3 \\
\hline \multicolumn{2}{c|}{ NPKM-1 } \\
\hline NPKM-2 \\
NPKM-3
\end{tabular}

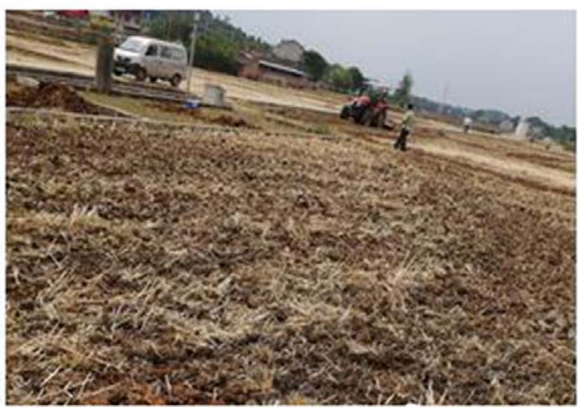

Figure 1. Field trial layout. Note: CK, without any fertilizer, NPK, pure chemical fertilizer, and NPKM, chemical fertilizer combined with organic fertilizer.

Table 1. The application of fertilizer dose $\left(\mathrm{kg} \cdot \mathrm{hm}^{2}\right)$.

\begin{tabular}{cccccc}
\hline Crop season & Treatment & $\mathrm{N}$ & $\mathrm{P}_{2} \mathrm{O}_{5}$ & $\mathrm{~K}_{2} \mathrm{O}$ & Organic fertilizer \\
\hline Wheat & $\mathrm{CK}$ & 0 & 0 & 0 & 0 \\
& $\mathrm{NPK}$ & 132.23 & 34.54 & 48.88 & 0 \\
& $\mathrm{NPKM}$ & 132.23 & 34.54 & 48.88 & 5000 \\
\multirow{2}{*}{ Rice } & $\mathrm{CK}$ & 0 & 0 & 0 & 0 \\
& $\mathrm{NPK}$ & 183.51 & 34.54 & 48.88 & 0 \\
& $\mathrm{NPKM}$ & 183.51 & 34.54 & 48.88 & 5000 \\
\hline
\end{tabular}

\subsection{Sampling and Measurements}

After the rice harvest in late May 2018, each plot was divided into three parts. Mixed soil samples in each part were gathered from five evenly distributed points, and a total of 45 mixed samples were collected from 0 to $100 \mathrm{~cm}(20 \mathrm{~cm}$ per layer, a total of 5 layers). The soil sample was separated into two parts after removing all visible animal and plant residues, stones and other debris, some of them were freshly stored at $4^{\circ} \mathrm{C}$ for the determination of soil $\mathrm{NH}_{4}^{+}-\mathrm{N}$ and $\mathrm{NO}_{3}^{-}-\mathrm{N}$, and the rest were ground and screened $(0.15,2 \mathrm{~mm})$ after air-drying in a cool and ventilated place.

Refer to "soil investigation Laboratory Analysis method" [20]: Soil TN was determined by Kjeldahl nitrogen meter, Soil AN was hydrolyzed by $1 \mathrm{~mol} \mathrm{~L}^{-1}$ $\mathrm{NaOH}$ and absorbed by boric acid, $\mathrm{NH}_{4}^{+}-\mathrm{N}$ and $\mathrm{NO}_{3}^{-}-\mathrm{N}$ were determined by indophenol blue colorimetry and dual-band colorimetry, soil $\mathrm{pH}$ was determined by $\mathrm{pH}$ meter, and cation exchange capacity (CEC) was determined by ammonium acetate method [21].

\subsection{Statistical Analysis}

All statistical analyses were performed using the SPSS19.0 software and plotted 
with Excel 2010. Two-way ANOVA was performed to test the effects of fertilization treatments and soil depth gradient on nitrogen forms, $\mathrm{pH}$ and CEC. Data were expressed as mean values \pm S.E. (standard error). All the results were considered statistically significant at $\mathrm{P}<0.05$ unless otherwise stated. Multiple comparisons were performed by LSD method.

\section{Results}

\subsection{Nitrogen Forms in Topsoil}

It can be seen from Table 2 that long-term fertilizations significantly affected the content of nitrogen forms in topsoil (soil layer of $0-20 \mathrm{~cm}$ ). Compared with $\mathrm{CK}$, the soil TN content in NPK and NPKM treatments increased by $64 \%$ and $59 \%$, soil AN increased by $65 \%$ and $61 \%$, soil $\mathrm{NO}_{3}^{-}-\mathrm{N}$ content increased by $70 \%$ and $111 \%$, and $\mathrm{NH}_{4}^{+}-\mathrm{N}$ content increased by $45 \%$ and $42 \%$, respectively. The contents of $\mathrm{AN}$ and $\mathrm{NO}_{3}^{-}-\mathrm{N}$ in soil treated with NPKM were significantly better than those of NPK.

\subsection{Effects of Long-Term Fertilization on Nitrogen Forms along Soil Depth Gradient}

\subsubsection{The Contents of $\mathrm{TN}, \mathrm{AN}, \mathrm{NH}_{4}^{+}-\mathrm{N}$ and $\mathrm{NO}_{3}^{-}-\mathrm{N}$}

The distribution of nitrogen forms in paddy soil profile is shown in Figure 2. It is not difficult to find that fertilization increased the content of soil nitrogen forms. The contents of soil TN and AN decreased gradually with soil depth. While obvious faults appeared in the $40 \mathrm{~cm}$ soil layer, and the nitrogen compositions in the $0-40 \mathrm{~cm}$ soil layer were significantly higher than those below $40 \mathrm{~cm}$ soil layer. In $20-40 \mathrm{~cm}$, the contents of TN and AN in NPK treatment were significantly higher than those in NPKM treatment, which increased by $62 \%$ and $20 \%$, respectively. The content of $\mathrm{NO}_{3}^{-}-\mathrm{N}$ decreased gradually with soil depth, and the differences of below $60 \mathrm{~cm}$ soil layer were not significant. $\mathrm{NH}_{4}^{+}-\mathrm{N}$ had an obvious downward migration tendency, and NPK and NPKM in $0-100 \mathrm{~cm}$ soil layer were significantly higher than CK, especially NPKM significantly increased the $\mathrm{NH}_{4}^{+}-\mathrm{N}$ of $60-80 \mathrm{~cm}$ soil, compared with NPK.

\subsubsection{Vertical Change of the Proportion of Nitrogen Forms}

The ratios of all forms of nitrogen are shown in Figure 3. The ratios of AN/TN and $\mathrm{NH}_{4}^{+}-\mathrm{N} / \mathrm{TN}$ in soil profiles fluctuated in a certain range. The ratios of AN/TN in CK, NPK and NPKM treatments fluctuated in the range of $4.31 \%$ to

Table 2. The content of soil nitrogen forms in fertilization.

\begin{tabular}{|c|c|c|c|c|c|c|c|}
\hline Treatments & $\begin{array}{c}\mathrm{TN} \\
\left(\mathrm{g} \cdot \mathrm{kg}^{-1}\right)\end{array}$ & $\begin{array}{c}\mathrm{AN} \\
\left(\mathrm{mg} \cdot \mathrm{kg}^{-1}\right)\end{array}$ & $\begin{array}{c}\mathrm{NO}_{3}^{-}-\mathrm{N} \\
\left(\mathrm{mg} \cdot \mathrm{kg}^{-1}\right)\end{array}$ & $\begin{array}{r}\mathrm{NH}_{4}^{+}-\mathrm{N} \\
\left(\mathrm{mg} \cdot \mathrm{kg}^{-1}\right)\end{array}$ & $\begin{array}{c}\mathrm{AN} / \mathrm{TN} \\
(\%)\end{array}$ & $\begin{array}{c}\mathrm{NO}_{3}^{-}-\mathrm{N} / \mathrm{TN} \\
(\%)\end{array}$ & $\begin{array}{c}\mathrm{NH}_{4}^{+}-\mathrm{N} / \mathrm{TN} \\
(\%)\end{array}$ \\
\hline $\mathrm{CK}$ & $0.54 \pm 0.01 b$ & $35.22 \pm 2.46 b$ & $12.52 \pm 0.23 c$ & $14.73 \pm 0.46 b$ & $6.47 \pm 0.47 a$ & $2.30 \pm 0.05 b$ & $2.70 \pm 0.11 \mathrm{a}$ \\
\hline NPK & $0.89 \pm 0.04 a$ & $43.78 \pm 2.18 \mathrm{a}$ & $21.27 \pm 2.32 b$ & $21.43 \pm 1.73 a$ & $4.91 \pm 0.17 b$ & $2.38 \pm 0.95 a$ & $2.40 \pm 0.19 a$ \\
\hline NPKM & $0.87 \pm 0.03 a$ & $47.39 \pm 2.37 \mathrm{a}$ & $26.46 \pm 1.72 \mathrm{a}$ & $20.91 \pm 1.28 \mathrm{a}$ & $5.46 \pm 0.25 b$ & $3.07 \pm 0.91 \mathrm{a}$ & $1.72 \pm 0.20 \mathrm{~b}$ \\
\hline
\end{tabular}

Note: different letters in the same column indicate significant differences between different treatments $(\mathrm{P}<0.05)$. 


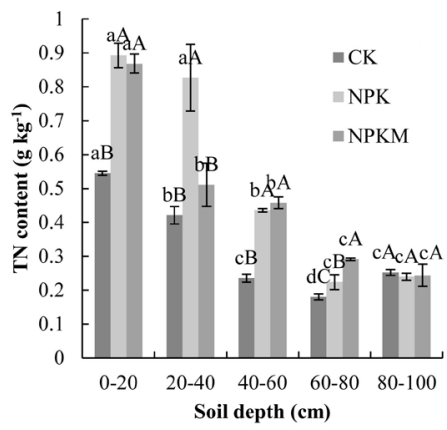

(a)

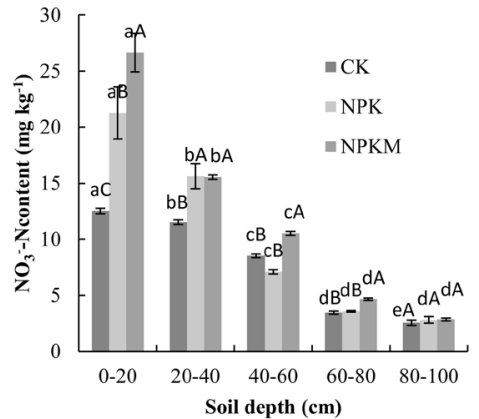

(c)

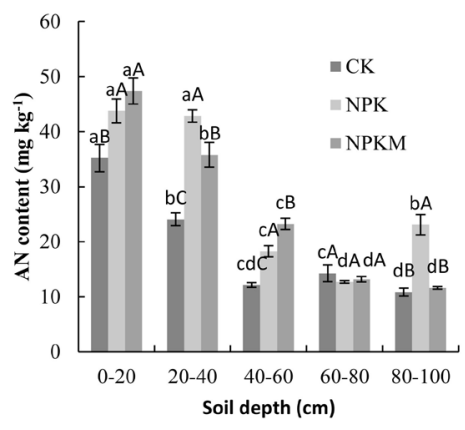

(b)

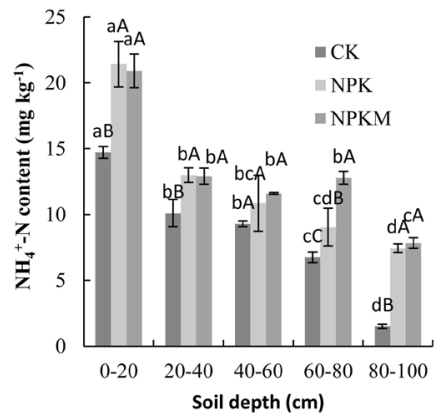

(d)

Figure 2. Distribution of nitrogen forms in $0-100 \mathrm{~cm}$ profiles of paddy. Note: Different lowercase letters indicate significant differences between soil layers; different uppercase letters indicate significant differences between treatments $(\mathrm{P}<0.05)$.

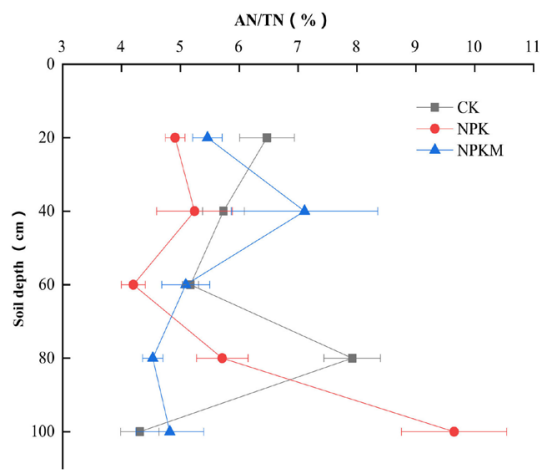

(a)

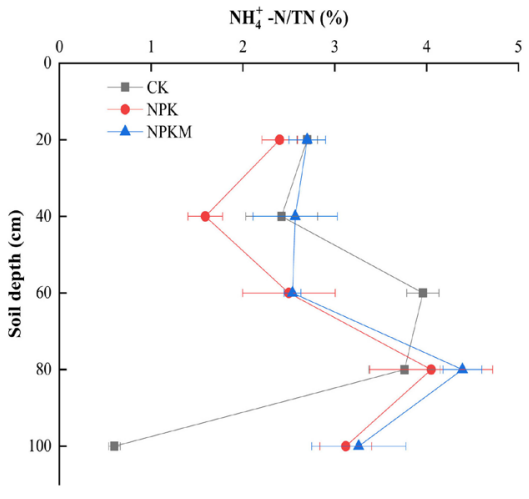

(b)

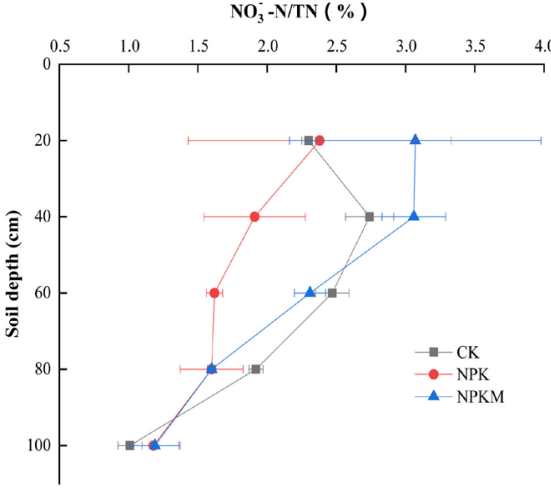

(c)

Figure 3. Vertical variations of the ratios of nitrogen in long-term fertilization. 
$7.92 \%, 4.2 \%$ to $9.65 \%$ and $4.53 \%$ to $7.11 \%$, respectively. The AN/TN ratio in NPK and NPKM treatments increased at first and then decreased in $0-60 \mathrm{~cm}$ soil layer. The trend of $\mathrm{NH}_{4}^{+}-\mathrm{N} / \mathrm{TN}$ ratio was opposite to that of $\mathrm{AN} / \mathrm{TN}$, and it decreased at first and then increased in $0-80 \mathrm{~cm}$ soil layer. The $\mathrm{NO}_{3}^{-}-\mathrm{N} / \mathrm{TN}$ ratio decreased gradually with the soil depth. It was worth mentioning that in 0 $60 \mathrm{~cm}$ soil layer, the ratios of $\mathrm{AN} / \mathrm{TN}, \mathrm{NH}_{4}^{+}-\mathrm{N} / \mathrm{TN}$ and $\mathrm{NO}_{3}^{-}-\mathrm{N} / \mathrm{TN}$ in NPKM were significantly higher, relative to NPK.

\subsection{Effects of Long-Term Fertilization on the Contents of $\mathrm{pH}$ and CEC along Soil Depth Gradient}

It can be seen from Table 3 that compared with NPK, the increase of soil $\mathrm{pH}$ in NPKM treatment significantly alleviated soil acidification caused by long-term chemical fertilizer application. The soil $\mathrm{pH}$ in NPK treatment increased with the soil depth, but there was no significant difference. Different from soil $\mathrm{pH}$, soil CEC of the three fertilization treatments decreased gradually along soil depth gradient. Compared with CK treatment, NPKM significantly increased the content of CEC in $0-20 \mathrm{~cm}$ soil, while NPK treatment significantly decreased it.

\subsection{Correlation between Nitrogen Forms and Soil Properties}

The correlation between nitrogen forms ( $\mathrm{TN}, \mathrm{AN}, \mathrm{NO}_{3}^{-}-\mathrm{N}, \mathrm{NH}_{4}^{+}-\mathrm{N}$ ) and soil properties ( $\mathrm{pH}$ and $\mathrm{CEC}$ ) were analyzed, and the results were shown in Table 4 below. There was a strong correlation among different soil nitrogen forms $(\mathrm{P}<$ 0.01). There was no significant correlation between soil nitrogen forms and $\mathrm{pH}$, but there was a significant positive correlation between soil nitrogen forms and CEC $(\mathrm{P}<0.05)$.

\section{Discussion}

Nitrogen is one of the factors that determine the yield of crops and the status of soil fertility in farmland [22]. The availability of nitrogen in surface soil is a direct reflection of human activities like fertilization and tillage [23] [24]. Nitrate nitrogen is the most active nitrogen forms that can be directly absorbed and

Table 3. Effect of fertilization treatments on $\mathrm{pH}$ and the content of CEC.

\begin{tabular}{cccccccc}
\hline Indicators & treatments & $0-20 \mathrm{~cm}$ & $20-40 \mathrm{~cm}$ & $40-60 \mathrm{~cm}$ & $60-80 \mathrm{~cm}$ \\
\hline & $\mathrm{CK}$ & $7.59 \pm 0.02 \mathrm{aA}$ & $7.58 \pm 0.04 \mathrm{aA}$ & $7.39 \pm 0.07 \mathrm{bA}$ & $7.65 \pm 0.01 \mathrm{aA}$ \\
$\mathrm{pH}$ & $\mathrm{NPK}$ & $6.45 \pm 0.01 \mathrm{bB}$ & $6.46 \pm 0.01 \mathrm{abB}$ & $6.49 \pm 0.02 \mathrm{abB}$ & $6.49 \pm 0.06 \mathrm{abB}$ & $6.56 \pm 0.07 \mathrm{aB}$ \\
& $\mathrm{NPKM}$ & $7.56 \pm 0.02 \mathrm{aA}$ & $7.63 \pm 0.05 \mathrm{aA}$ & $7.45 \pm 0.03 \mathrm{bA}$ & $7.45 \pm 0.05 \mathrm{bA}$ & $7.63 \pm 0.01 \mathrm{aA}$ & $100 \mathrm{~cm}$ \\
& $\mathrm{CK}$ & $15.38 \pm 0.12 \mathrm{aB}$ & $13.53 \pm 0.52 \mathrm{bA}$ & $10.95 \pm 0.43 \mathrm{cB}$ & $11.07 \pm 0.46 \mathrm{cB}$ & $10.56 \pm 0.47 \mathrm{cAB}$ \\
$\mathrm{CEC}$ & $\mathrm{NPK}$ & $14.05 \pm 0.42 \mathrm{aC}$ & $13.88 \pm 0.16 \mathrm{aA}$ & $12.75 \pm 0.27 \mathrm{bA}$ & $11.18 \pm 0.53 \mathrm{cB}$ & $11.04 \pm 0.15 \mathrm{cA}$ \\
$\left(\mathrm{cmol} \cdot \mathrm{kg}^{-1}\right)$ & $\mathrm{NPKM}$ & $16.7 \pm 50.29 \mathrm{aA}$ & $14.2 \pm 0.55 \mathrm{bA}$ & $12.4 \pm 0.27 \mathrm{dA}$ & $13.26 \pm 0.28 \mathrm{cA}$ & $10.18 \pm 0.11 \mathrm{eB}$ \\
\hline
\end{tabular}

Note: Different lowercase letters indicate significant differences between soil layers; different uppercase letters indicate significant differences between treatments $(\mathrm{P}<0.05)$. 
Table 4. Correlation between soil nitrogen forms and soil properties.

\begin{tabular}{cccccc}
\hline Indicators & $\mathrm{TN}$ & $\mathrm{AN}$ & $\mathrm{NO}_{3}^{-}-\mathrm{N}$ & $\mathrm{NH}_{4}^{+}-\mathrm{N}$ & $\mathrm{pH}$ \\
\hline $\mathrm{AN}$ & $0.925^{* *}$ & & $\cdot$ & & \\
$\mathrm{NO}_{3}^{-}-\mathrm{N}$ & $0.889^{* *}$ & $0.814^{* *}$ & & & \\
$\mathrm{NH}_{4}^{+}-\mathrm{N}$ & $0.777^{* *}$ & $0.754^{* *}$ & $0.774^{* *}$ & & \\
$\mathrm{pH}$ & -0.122 & 0.057 & -0.108 & -0.152 & \\
$\mathrm{CEC}$ & $0.803^{* *}$ & $0.818^{* *}$ & $0.825^{* *}$ & $0.734^{* *}$ & 0.061
\end{tabular}

Note: ${ }^{*}$ Significant correlation at 0.01 level (bilateral).

utilized by crops [25], and it is easy to leach into the ground with Rain Water. Therefore, high concentrations of $\mathrm{NO}_{3}^{-}-\mathrm{N}$ accumulated in the soil, which greatly increased the risk of nitrogen leaching [26]. This study showed that fertilization was closely related to the content of soil nitrogen forms in paddy (Table 2). Compared with non-fertilization plot, long-term fertilization significantly increased the content of active nitrogen forms in topsoil (soil layer of $0-20 \mathrm{~cm}$ ), which was consistent with Hao et al. [27]. Zhu et al. [28] also showed that the topsoil $\mathrm{NO}_{3}^{-}-\mathrm{N}$ content in long-term chemical fertilizer combined with organic fertilizer plot was higher, compared to pure chemical fertilizer, indicating that combined application of organic-inorganic fertilizer promoted nitrogen mineralization and provided sufficient nitrogen for rice growth. Due to organic fertilizer increased the number of soil microorganisms, which was largely offset by the nitrogen residues fixed by microorganisms. Chemical fertilizer can stimulate soil nitrogen mineralization and increase nitrogen content [29]. Therefore, it was also observed that the TN content in $0-40 \mathrm{~cm}$ soil layer of pure chemical fertilizer plot was higher (Figure 2(a)).

Many studies have shown that long-term fertilization significantly affected the distribution of nitrogen forms in the vertical plane of soil [30] [31]. Our study also showed that the content of soil nitrogen forms decreased gradually with soil depth, and long-term fertilization slowed down the downward trend (Figure 2). This is because fertilization and tillage mainly act on the plough layer, the less the effect is, the nitrogen content in the soil profile showed the phenomenon of "surface aggregation" [32]. While nitrogen fertilizer increased nitrogen source and promoted nitrogen mineralization. The accumulation of a large amount of nitrogen in surface soil increased the infiltration of nutrients [33]. In the $20-40$ $\mathrm{cm}$ soil layer, compared with pure chemical fertilizer plot, the application of organic-inorganic fertilizer significantly reduced the content of soil $\mathrm{NO}_{3}^{-}-\mathrm{N}$ and delayed its leaching into the deep soil, which indicated that the organic fertilizer had a better fertilizer conservation performance. This may be due to the fact that organic fertilizer could dissociate $\mathrm{H}^{+}$in the solution, so that the soil had a strong cation exchange capacity [34]. In addition, long-term application of organic-inorganic fertilizers may increase the biological residues of crops and promote the metabolism of microorganisms [35]. It was also found that relative to pure 
chemical fertilizer, organic fertilizer increased the content of $\mathrm{NO}_{3}^{-}-\mathrm{N}$ in $0-20$ $\mathrm{cm}$ soil layer. However, in $20-40 \mathrm{~cm}$ soil layer, NPK fertilization increased the content of TN and AN. This showed that soil nitrogen forms showed different responses to different fertilization treatments. The ratios of soil active nitrogen to total nitrogen can better reflect the quality of soil. In this study, AN/TN, $\mathrm{NH}_{4}^{+}$-N/TN and $\mathrm{NO}_{3}^{-}$-N/TN treated by organic-inorganic fertilizer were higher in $0-60 \mathrm{~cm}$ soil layer, compared with pure chemical fertilizer (Figure 3). Similarly, Li et al. [36] studied the double-cropping rice soil and found that inorganic combined with organic fertilizer increased the proportion of active nitrogen forms to TN.

Soil physical and chemical properties like $\mathrm{CEC}$ and $\mathrm{pH}$ play important roles in soil quality evaluation. Soil CEC can directly reflect soil nutrition supply, nutrition conservation and buffering capacity [37]. Soil CEC increased after application of organic fertilizer [38]. This study also showed that the organic-inorganic fertilizers significantly increased the soil CEC (Table 3 ). This is probably because the long-term application of organic fertilizer increased the content of organic matter, thus reducing the amount of variable negative charge. As most of the common chemical fertilizers are acidic, long-term application tends to reduce soil $\mathrm{pH}$, resulting in soil consolidation, nutrient imbalance, fertilizer use efficiency and other problems. The combined application of organic fertilizer alleviated soil acidification, mainly because organic functional groups can absorb more $\mathrm{H}^{+}$and $\mathrm{Al}^{3+}$, organic matter decarboxylation in the process of mineralization, and release basic substances such as calcium and magnesium, thus increasing soil $\mathrm{pH}$ value. In addition, the correlation analysis between soil nitrogen forms and $\mathrm{pH}$, CEC showed that there was a significant positive correlation among different soil nitrogen forms (Table 4). This showed that AN may reflect the status of soil nitrogen nutrients to some extent. There was a significant positive correlation between soil CEC and nitrogen forms, which was related to the easy leaching of available nutrients such as nitrate nitrogen and ammonium nitrogen [39].

\section{Conclusions}

The main results were as follows:

1) Compared with the non-fertilization treatment, long-term fertilization treatment significantly increased the content of nitrogen forms in topsoil (soil layer of $0-20 \mathrm{~cm}$ ). Compared with chemical fertilizer alone, organic-inorganic fertilizer significantly increased the content of $\mathrm{NO}_{3}^{-}-\mathrm{N}$ in topsoil, which was beneficial to promote the mineralization of nitrogen fertilizer.

2) The contents of nitrogen forms decreased gradually with soil depths. However, fertilization alleviated the decline to some extent, especially organic fertilizer effectively increased the proportion of $\mathrm{NH}_{4}^{+}-\mathrm{N} / \mathrm{TN}$ and $\mathrm{NO}_{3}^{-}-\mathrm{N} / \mathrm{TN}$ in 0 $60 \mathrm{~cm}$ soil layer. In addition, organic fertilizer increased soil $\mathrm{pH}$ and CEC, preventing soil acidification and improving soil fertilizer conservation. 
3) There was a significant positive correlation among different soil nitrogen forms. Compared with other nitrogen forms, there was a very significant positive correlation between AN and CEC. The effect of long-term fertilization on soil fertilizer conservation could be observed through the change of AN.

\section{Acknowledgements}

The authors would like to acknowledge the support of the National Key Research and Development Program of China [2017YFD0301701], the Key Project of Sichuan Tobacco Company (No. SCYC201803) and the Key Program of Sichuan Tobacco Company Liangshanzhou Company (No. LSYC201801).

\section{Conflicts of Interest}

The authors declare no conflicts of interest regarding the publication of this paper.

\section{References}

[1] Cai, H.C. (2000) Present situation and Development Prospect of Rice production in China. China Rice, 6, 5-8.

[2] Wang, D., Ye, C., Xu, C., Wang, Z., Chen, S., Chu, G. and Zhang, X. (2019) Soil Nitrogen Distribution and Plant Nitrogen Utilization in Direct-Seeded Rice in Response to Deep Placement of Basal Fertilizer-Nitrogen. Rice Science, 26, 404-415. https://doi.org/10.1016/j.rsci.2018.12.008

[3] Dong, Y., Yuan, J., Zhang, G., Ma, J., Hilario, P., Liu, X. and Lu, S. (2020) Optimization of Nitrogen Fertilizer Rate under Integrated Rice Management in a Hilly Area of Southwest China. Pedosphere, 30, 759-768. https://doi.org/10.1016/S1002-0160(20)60036-4

[4] Zhang, G., Li, J., Xu, M. and Gu, S. (2009) Effects of Chemical Fertilizer and Organic Manure on Rice Yield and Soil Fertility. Scientia Agricultura Sinica, 42, 543-551.

[5] Nan, Z., Liang, B., Chen, Y., Liu, S. and Liu, J. (2016) Effect of Long-Term Fertilization on Soil Nitrogen Mineralization and Crop Yield. Acta Agriculturae Boreali-Sinica, 31, 146-151.

[6] Ma, L., Yang, L., Yan, T., Wang, J., Li, D. and Yin, S. (2010) Profile Distribution and Mineralization Characteristics of Nitrogen in Relation to Temperature in Paddy Soil under Long-Term Fertilization. Acta Pedologica Sinica, 2, 286-294.

[7] Zhao, D., Liu, K., Ye, H., Hu, Z., Yu, X., Xu, X., Yang, X., Zhou, L., Hu, Q., Hu, H. and Huang, Q. (2018) Differences of Soil Nutrient Distribution in Profiles under Long-Term Fertilization in Upland Red Soil. Journal of Plant Nutrition and Fertilizers, 24, 633-640.

[8] Zhao, J., Fan, X., He, H., Kong, L., Li, W. and Liang, T. (2019) Effect of Long-Term Fertilization on Available Nitrogen, Phosphorus and Potassium in Soil. Bulletin of Agricultural Science and Technology, 2, 116-118.

[9] Fan, J., He, M. and Dang, T. (2000) Distribution and Accumulation of $\mathrm{NO}_{3}^{-}-\mathrm{N}$ in soil Profile of Long-Term Located Fertilizer Experiment. Soil and Environmental Sciences, 9, 23-26.

[10] Fan, J., He, M. and Dang, T. (2001) Effect of Long-Term Fertilization on Nutrient Distribution in Profiles of Black Loessial Soil. Journal of Plant Nutrition and Ferti- 
lizers, 7, 249-254.

[11] Yu, H. and Zhang, E. (2014) Effects of Long-Term Fertilization on Soil Organic Nitrogen Fractions in Vegetable Soil. Liaoning Agricultural Sciences, 1, 13-16.

[12] Xie, S., Yang, F., Feng, H., Yu, Z., Liu, C. and Wei, C. (2020) Organic Fertilizer Reduced Carbon and Nitrogen in Runoff and Buffered Soil Acidification in Tea Plantations: Evidence in Nutrient Contents and Isotope Fractionations. Science of the Total Environment, 15, Article ID: 143059. https://doi.org/10.1016/j.scitotenv.2020.143059

[13] Nie, S., Huang, S., Zhang, S., Guo, D., Zhang, Q., Zhang, Y., Bao, D. and Chen, Y. (2012) Effects of Long-Term Fertilization on Soils: A Review. Soils, 44, 188-196.

[14] Pernes-debuyser, A. and Tessier, D. (2004) Soil Physical Properties Affected by Long-Term Fertilization. European Journal of Soil Science, 55, 505-512. https://doi.org/10.1111/j.1365-2389.2004.00614.x

[15] Menéndez, S., Lopez-Bellido, R.J., Benitez-Vega, J., González-Murua, C., López-Bellido, L. and Estavillo, J.M. (2008) Long-Term Effect of Tillage, Crop Rotation and N Fertilization to Wheat on Gaseous Emissions under Rainfed Mediterranean Conditions. European Journal of Agronomy, 28, 559-569. https://doi.org/10.1016/j.eja.2007.12.005

[16] Ou, J. and Zhang, H. (2017) Study on the Effect of Long-Term Located Fertilization on Wheat Yield and Soil Fertility. Agricultural Science and Engineering in China, 29, $18-20+50$.

[17] Zhao, D., Wang, J. and Fu, X. (2016) Effect of Long-Term Fertilization on Soil Total Nitrogen and Its Fractions in Dryland Farming System. Journal of Soil and Water Conservation, 30, 303-307.

[18] Zhao, P., Han, M., Xiong, Z. and Guo, T. (2018) Effects of Long-Term Fertilization on the Nitrification and Ammoxidation in Neutral Purple Soil. Soil and Fertilizer Sciences in China, No. 5, 85-90.

[19] Zhang, Q., Zhang, X., Liang, B., Bi, M. and Li, J. (2017) Effects of Long-Term Fertilization on the Dynamics of Soil Enzyme Activity and Soil Nutrient under the Greenhouse Tomato-Cultivating System. Acta Agriculturae Boreali-Sinica, 32, 179-186.

[20] Zhang, G. and Gong, Z. (2012) Laboratory Analysis Methods for Soil Investigation. Science Press, Beijing.

[21] Li, J., Zhai, M., Huang, B., Liu, G., Zhao, Y., Sun, W. and Hu, W. (2017) Spatially Non-Stationary Relationships between Cation Exchange Capacity and Related Control Factors. Acta Pedologica Sinica, 54, 638-646.

[22] Li, J., Xin, J., Zhang, H., Duan, J., Ren, Y., Sun, N. and Xu, M. (2015) Evolution Characteristics of Soil Nutrients in the Main Rice Production Regions, the Middle-Lower Reach of Yangtze River of China. Journal of Plant Nutrition and Fertilizers, 21, 92-103.

[23] Gurlevik, N., Kelting, D.L. and Allen, H.L. (2004) Nitrogen Mineralization Following Vegetation Control and Fertilization in a 14-Year-Old Loblolly Pine Plantation. Soil Science Society of America Journal, 68, 272-281. https://doi.org/10.2136/sssaj2004.2720

[24] Bhandari, A.L., Ladha, J.K., Pathak, H., Padre, A.T., Dawe, D. and Gupta, R.K. (2002) Yield and Soil Nutrient Changes in a Long-Term Rice-Wheat Rotation in India. Soil Science Society of America Journal, 66, 162-172.

https://doi.org/10.2136/sssaj2002.1620a

[25] Su, N., Yang, L., Zhou, C., Jie, X., Qu, H. and Gao, X. (2006) Effect of the Applica- 
tion of Organic and Nitrogen Fertilizer on the Content of Alkali-Hydrolysable $\mathrm{N}$ in Soil. Journal of Anhui Agricultural Sciences, 34, 6542-6543.

[26] Xu, J. and Wang, H. (2001) The Nitrogen Fertilizer Utilization and Nitrogen Balance by Winter Wheat in Sandy Soil. Journal of Nuclear Agricultural Sciences, 6, 476-480.

[27] Hu, R., Wu, J., Tang, S. and Luo, X. (2010) Effects of Long-Term Fertilization on Paddy Soils Organic Nitrogen, Microbial Biomass, and Microbial Functional Diversity. Chinese Journal of Applied Ecology, 6, 130-137.

[28] Zhu, Y. (2016) Effect of Long-Term Fertilization on Soil Organic Nitrogen Composition and Its Relationship with Nitrogen Index. Shenyang Agricultural University, Shenyang.

[29] Zhu, Z.L. (2008) Research on Soil Nitrogen in China. Acta Pedologica Sinica, 45, 778-783.

[30] Malhi, S.S., Gill, K.S., Harapiak, J.T., Nyborg, M., Gregorich, E.G. and Monreal, C.M. (2003) Light Fraction Organic N, Ammonium, Nitrate and Total N in a Thin Black Chernozemic Soil under Brome Grass after 27 Annual Applications of Different N Rates. Nutrient Cycling in Agroecosystems, 65, 201-210. https://doi.org/10.1023/A:1022623405707

[31] Zhang, X., An, J., Zhou, X. and Sui, S. (2012) Effect of Different Fertilization Modes on Maize Yield and Soil Nitrate-Nitrogen. Journal of Henan Agricultural Sciences, 41, 41-44.

[32] Shi, J., Li, X., Wang, S., Li, S., Li, Y. and Tian, X. (2015) Effect of Long-Term Shallow Tillage and Straw Returning on Soil Potassium Content and Stratification Ratio in Winter Wheat/Summer Maize Rotation System in Guanzhong Plain, Northwest China. Chinese Journal of Applied Ecology, 26, 3322-3328.

[33] Huang, T. (2014) The Mechanism of the Effect of Long-Term Carbon and Nitrogen Input on Soil Organic Carbon and Nitrogen Pool and Environment. China Agricultural University, Beijing.

[34] Zhao, Y. Tong, Y. and Zhao, H. (2006) Effect of Different N Rates on Yield of Summer Maize, Fertilizer N Recovery and N Balance. Soil Fertilizer, 2, 30-33.

[35] Zhang, J., Wang, C., Li, B., Liang, J., He, J., Xiang, H., Yin, B. and Luo, J. (2017) Effects of Controlled Release Blend Bulk Urea on Soil Nitrogen and Soil Enzyme Activity in Wheat and Rice Fields. Chinese Journal of Applied Ecology, 28, 1899-1908.

[36] Li, W., Peng, B. and Yang, Q. (2015) Effects of Long-Term Fertilization on Organic Carbon and Nitrogen Accumulation and Activity in a Paddy Soil in Double Cropping Rice Area in Dongting Lake of China. Scientia Agricultura Sinica, 48, 488-500.

[37] Bi, C., Chen, Z., Wang, J. and Zhou, D. (2013) Quantitative Assessment of Soil Health under Different Planting Patterns and Soil Types. Pedosphere, 23, 194-204. https://doi.org/10.1016/S1002-0160(13)60007-7

[38] Luo, Y., Li, Z. and Liu, W. (2011) Effects of Long-Term Located Fertilization on Organic Matter, Nutrient and CEC in Upland Red Soil. Acta Agriculturae Jiangxi, 23, 133-136.

[39] Wang, J. and Zhang, Y. (2011) Effects of Different Fertilization Systems on Soil CEC and Soil Acidity in Paddy Field. Chinese Journal of Soil Science, 42, 42-45. 